\title{
PERAMALAN PENERIMAAN BEA CUKAI INDONESIA
}

\author{
Yolanda Sari dan Nurlia Fusfita \\ STIE Muhammadiyah Jambi
}

\begin{abstract}
The revenue of customs and excise is very important in APBN. By making accurate estimation, target of revenue can be better determined. In addition, the revenue of customs and excise is also influenced by many external factors that are difficult to predict therefore a rational approach is needed to estimate revenue. This research uses Double Exponential Smoothing, Ordinary Least Square (OLS) model and Moving Average in predicting customs and excise revenue. Data used in this research is secondary data in time coherent pattern. The data includes import duty, export duty and excise obtained from the Directorate General of Customs and excise (DJBC) in the form of annual and quarterly data. This data starts from 2002 to 2016 with out of sample from 2017 to 2019. Some of these models are compared to each other to obtain the best model, and from the best model is also obtained estimating results in 3 years ahead. This study shows that the Double Exponential Smoothing model is better for predicting import duties compared to OLS and Moving Average models, which are models that have the smallest Sum Square Error (SSE) value. While the export and excise duty is best estimated by using OLS model which is shown with coefficient of determination value $(R 2)$ regression model of export duty is 0.8 , while the excise regression model has coefficient of determination of 0.9 .
\end{abstract}

Keywords: Customs Estimation, Double Exponential Smoothing, Ordinary Least Square, Moving Average

\section{PENDAHULUAN}

Bea Cukai saat ini memiliki peranan yang cukup besar dalam memberikan masukan kepada penerimaan negara non-pajak. Pada tahun 2014 penerimaan cukai dalam APBN adalah sebesar 117,4 triliun rupiah dan 56,3 triliun rupiah untuk bea masuk dan keluar; dan diproyeksikan akan menjadi sebesar 125,9 triliun rupiah untuk cukai dan 51,5 triliun rupiah untuk bea masuk dan keluar pada tahun 2015 (Departemen Keuangan, 2014). Peranan penerimaan bea-cukai untuk membiayai pengeluaran negara menjadi penting karena belum optimalnya penerimaan pajak negara yang tax ratio-nya baru mencapai sekitar $12 \%$ untuk pajak pusat (Hidayat, 2014). Di sisi lain, penerimaan bea dan cukai mengalami fluktuasi yang banyak dipengaruhi faktor eksternal, seperti permintaan dan penawaran komoditi di pasar internasional. Aktivitas ekonomi, pendapatan, dan ekpektasi masyarakat juga merupakan faktor penting yang mempengaruhi penerimaan bea dan cukai.

Masalah yang muncul di lapangan adalah sulitnya memprediksi besaran nilai bea masuk dan cukai yang dapat digunakan untuk pembiayaan APBN. Hal itu dipersulit dengan semakin tidak menentunya kondisi perekonomian global dengan penurunan harga minyak yang berpengaruh signifikan terhadap harga komoditi lainnya di pasar internasional. Di sisi lain, kebutuhan untuk dapat memprediksi dengan akurat merupakan salah satu syarat untuk dapat melakukan perencanaan pembiayaan yang baik. 
Estimasi penerimaan bea cukai sangat penting untuk dapat dilakukan dengan baik karena peran jenis penerimaan sangat penting di dalam APBN. Dengan melakukan estimasi yang akurat, penentuan target penerimaan dapat ditentukan dengan lebih baik. Kedua, penerimaan bea dan cukai dipengaruhi banyak faktor eksternal yang seringkali sulit diprediksi dengan menggunakan intuisi dan pengalaman di masa lalu. Untuk itu diperlukan pendekatan yang secara rasional dapat dipertanggungjawabkan untuk mengestimasi penerimaan. Kemampuan dalam mengestimasi penerimaan ini akan meningkatkan efektifitas dan efisiensi perencanaan negara terkait dengan pembiayaan pembangunan melalui APBN. Dengan penentuan target yang akurat, perencanaan pembiayaan pembangunan dan pengeluaran publik pemerintah dapat berjalan lebih baik.

\section{Tinjauan Pustaka Bea Cukai}

Bea dan Cukai (selanjutnya disebut Bea Cukai) merupakan institusi global yang hampir semua negara di dunia memilikinya. Bea Cukai merupakan perangkat negara "konvensional" seperti halnya kepolisian, kejaksaan, pengadilan, ataupun angkatan bersenjata, yang eksistensinya telah ada sepanjang masa sejarah negara itu sendiri. Fungsi Bea Cukai di Indonesia diyakini sudah ada sejak zaman kerajaan dahulu, namun belum ditemukan bukti-bukti tertulis yang kuat. Kelembagaannya pada waktu itu masih bersifat "lokal" sesuai wilayah kerajaannya. Sejak VOC masuk, barulah Bea Cukai mulai terlembagakan secara "nasional". Pada masa Hindia Belanda tersebut, masuk pula istilah douane untuk menyebut petugas Bea Cukai. Nama resmi Bea Cukai pada masa Hindia Belanda tersebut adalah De Dienst der Invoer en Uitvoerrechten en Accijnzen (I. U \& A) atau dalam terjemah bebasnya berarti "Dinas Bea Impor dan Bea Ekspor serta Cukai". Tugasnya adalah memungut invoer-rechten (bea impor/masuk), uitvoerrechten (bea ekspor/keluar), dan accijnzen (excise/ cukai). Tugas memungut bea (berasal dari bahasa Sansekerta), baik impor maupun ekspor, serta cukai (berasal dari bahasa India) inilah yang kemudian memunculkan istilah Bea dan Cukai di Indonesia.

Peraturan yang melandasi saat itu di antaranya Gouvernment Besluit Nomor 33 tanggal 22 Desember 1928 yang kemudian diubah dengan keputusan pemerintah tertanggal 1 Juni 1934. Pada masa pendudukan Jepang, berdasarkan Undang-undang Nomor 13 tentang Pembukaan Kantor-kantor Pemerintahan di Jawa dan Sumatera tanggal 29 April 1942, tugas pengurusan bea impor dan bea ekspor ditiadakan, Bea Cukai sementara hanya mengurusi cukai saja. Lembaga Bea Cukai setelah Indonesia merdeka, dibentuk pada tanggal 01 Oktober 1946 dengan nama Pejabatan Bea dan Cukai. Saat itu Menteri Muda Keuangan, Sjafrudin Prawiranegara, menunjuk R.A Kartadjoemena sebagai Kepala Pejabatan Bea dan Cukai yang pertama. Jika ditanya kapan hari lahir Bea Cukai Indonesia, maka 1 Oktober 1946 dapat dipandang sebagai tanggal yang tepat. Berdasarkan Peraturan Pemerintah Nomor 51 tahun 1948, istilah Pejabatan Bea Cukai berubah menjadi nama menjadi Jawatan Bea dan Cukai, yang bertahan sampai tahun 1965 . Setelah tahun 1965 hingga sekarang, namanya menjadi Direktorat Jenderal Bea dan Cukai (DJBC) (DJBC Kemenkeu, 2013). 


\section{Peramalan}

Peramalan (forecasting) adalah kegiatan penerapan model yang telah dikembangkan pada waktu yang akan datang (Aritonang, 2009). Peramalan berperan penting dalam setiap bidang fungsional, baik dalam bidang keuangan, pemasaran, sumber daya manusia, produksi, dalam pemerintah maupun organisasi yang bertujuan laba, namun peramalan bukanlah pengganti dari perencanaan, peramalan adalah salah satu aspek dari perencanaan. Pada umumnya kegunaan peramalan adalah sebagai alat bantu dalam perencanaan yang efektif dan efisien, juga untuk menentukan kebutuhan sumber daya di masa mendatang serta untuk membuat keputusan yang tepat. Kegunaan peramalan terlihat pada suatu pengambilan keputusan. Baik tidaknya hasil suatu penelitian sangat ditentukan oleh ketetapan ramalan yang dibuat. Walaupun demikian perlu diketahui bahwa ramalan selalu ada unsur kesalahannya, sehingga yang perlu diperhatikan adalah usaha untuk memperkecil kesalahan dari ramalan tersebut.

\section{Model Double Exponential Smoothing}

Penyusunan model peramalan yang didasarkan pada discounted past observation secara umum dilakukan dengan menggunakan prosedur eksponensial. Prosedur ini mengijinkan model peramalan untuk memperbaharui (update) dirinya ketika data observasi yang baru tersedia. Persamaan smoothing didasarkan pada rata-rata (smoothing) nilai data yang lampau dari runtut waktu dengan perilaku yang menurun (eksponensial) (Cooray, 2008). Data yang diobservasi diberi bobot dengan bobot yang lebih besar untuk data observasi terbaru. Model peramalan berdasarkan exponential smoothing telah menjadi sangat populer karena mudah untuk diimplementasikan dan cukup efektif. Jika dalam suatu runtut waktu terdapat tren linier dengan persamaan regresi linier $x_{t}=a+b t$ di mana hasil estimasi $a$ dan $b$ merepresentasikan titik potong (intercept) dan kemiringan (slope) dari model, dan $t=1,2,3,4, \ldots, n$, maka prosedur eksponensial yang tepat adalah double exponential smoothing (Cooray, 2008).

Meskipun cenderung berpikir tentang tren sebagai garis lurus yang menaik atau menurun, untuk keperluan exponential smoothing, akan sangat membantu untuk berpikir tentang tren sebagai serangkaian perubahan dalam tingkat (level) (Mentzer dan Moon, 2004). Dalam kata lain, dengan setiap periode berturut-turut, level dapat melangkah naik (step up) atau turun (step down). Fungsi langkah (step function) atau perubahan pola tingkat dijelaskan pada Gambar 1. Walaupun terdapat tren menaik dalam bentuk garis lurus, kita dapat membayangkan tren sebagai rangkaian kenaikan pada level (garis horisontal putus-putus). Untuk periode $t+1$, tren adalah sebesar perubahan tingkat dari periode $t$ dengan periode $t+1\left(L_{t+1}-L_{t}\right)$, atau $T_{t+1}$. Demikian pula untuk periode $t+2$, tren adalah sebesar perubahan tingkat dari periode $t+1$ ke periode $t+2\left(L_{t+2}-L_{t+1}\right)$, atau $T_{t+2}$.

Untuk memahami perhitungan tren dalam exponential smoothing, kita perlu memahami single exponential smoothing yang rumusnya adalah sebagai berikut:

$F_{t+1}=\alpha S_{t}+(1-\alpha) F_{t}$

Dalam perhitungan ini, $S_{t}$ merupakan salah satu ukuran dari observasi di waktu lampau (data observasi terakhir) dan $F_{t}$ adalah ukuran lain dari observasi di waktu lampau (rata-rata tertimbang dari data observasi di semua periode sebelum t). Jadi, single exponential smoothing merupakan rata-rata tertimbang (weighted average) untuk dua ukuran dari suatu hal yang sama. Holt, et al. (1960) 
mengembangkan double exponential smoothing yang merupakan rata-rata tertimbang dari level dan tren. Rumus double exponential smoothing dalam Persamaan 2 sebagai berikut:

$L_{t+1}=\alpha Y_{t+1}+(1-\alpha)\left(L_{t}+T_{t}\right)$

$T_{t+1}=\beta\left(L_{t+1}-L_{t}\right)+(1-\beta) T_{t}$

$L$ menunjukkan level, $T$ menunjukkan tren, dan perlu diperhatikan bahwa nilai $\alpha$ dan $\beta$ adalah antara 0 hingga 1 . Rumus single exponential smoothing yang sebelumnya dalam Persamaan (1), tidak memasukkan unsur tren karena diasumsikan tidak ada. Oleh karena itu, peramalan di suatu periode didasarkan pada peramalan di periode sebelumnya.

Model double exponential smoothing dibutuhkan dua estimasi level untuk periode saat ini (Cooray, 2008). Estimasi pertama adalah data observasi untuk periode saat ini. Estimasi kedua dari level adalah perkiraan level dari periode sebelumnya. Dengan demikian terdapat dua ukuran dari level untuk exponentially smooth dengan $\alpha$ (Cooray, 2008). Kedua ukuran tren tersebut dihaluskan secara eksponensial menggunakan konstanta pemulusan, $\beta$. Sama halnya dengan $\alpha, \beta$ merupakan fraksi positif (yaitu, antara nol dan satu).

Setelah diperoleh estimasi baru untuk level $(L)$ dan tren $(T)$, maka dapat dilakukan peramalan di masa depan dengan menggunakan nilai level dan menambahkan tren per periode dikalikan jumlah periode ke depan yang ingin diestimasi. Hal ini dapat diwakili oleh rumus yang dijelaskan sebagai berikut, di mana $m$ adalah jumlah periode ke depan untuk dilakukan peramalan.

$F_{t+m}=L_{t}+\left(T_{t} \times m\right)$

\section{Model Ordinary Least Square}

Analisis regresi dalam pengembangannya dapat bersifat kompleks, yang disebabkan karakteristik data, pelanggaran asumsi statistik, nonstationarity, dsb. Analisis regresi akan dimulai dengan model yang paling sederhana. Model ini melibatkan dua variabel, yakni satu variabel independen dan satu variabel dependen.

\section{Representasi Regresi Sederhana}

Dalam analisis regresi sederhana, perubahan variabel dependen $(y)$ yang disebabkan oleh berubahnya variabel independen $(x)$, dapat direpresentasikan sebagai berikut:

$y=\beta_{0}+\beta_{1} x+u$

Di mana $y$ adalah variabel dependen dan $x$ variabel independen. Variabel $u$ disebut sebagai error term atau residual yang berfungsi untuk menampung seluruh faktor yang mempengaruhi $y$ selain $x$ (tidak terbatas pada variabel lain namun mungkin juga kesalahan bentuk fungsional, kesalahan pengukuran, dsb). Variabel $u$ juga seriing disebut sebagai variabel tak terobservasi (unobserved). Parameter $\beta_{1}$ disebut slope, sedangkan parameter $\beta_{0}$ disebut dengan intersep. Parameter $\beta_{1}$ menunjukkan kuantitas hubungan antara variabel independen dan variabel dependen dengan mengasumsikan seluruh faktor lain (yang tercakup dalam $u$ ) adalah konstan. Dalam persamaan, $\beta_{1}$ adalah linear, dengan demikian perubahan $x$ sebesar $\Delta x$ akan berimplikasi pada perubahan $y$ sebesar $\Delta y$. 


\section{Estimasi Model: Ordinary Least Squares}

Regresi memiliki dua pengertian fungsi regresi yang berbeda yaitu fungsi regresi populasi (population regression function $=\mathrm{PRF}$ ) dan fungsi regresi sampel (sample regression function $=\mathrm{SRF})$. Error term diperlukan mengingat hasil yang diperoleh dari sampel ini hanya merupakan suatu dugaan yang diharapkan berlaku atas dasar asumsi/prinsip statistik tertentu. Dengan kata lain selalu terdapat kemungkinan kesalahan atas dugaan populasi karena menggunakan data dari sampel.

Parameter $\beta_{0}$ dan $\beta_{1}$ dapat diestimasi dengan menggunakan teknik ordinary least squares (OLS). Secara intuitif kita dapat membayangkan penggunaan metode OLS sebagai pencarian suatu garis lurus yang melewati sekumpulan titik pasangan observasi (variabel dependen; $y$ dan variabel independen; $x$ ). Garis ini harus memenuhi suatu kriteria secara terbaik. Kriteria yang digunakan adalah meminimalkan selisih antara nilai prediksi yang diberikan oleh garis lurus tersebut dengan nilai aktualnya.

Secara lebih formal, penyelesaian permasalahan pencarian garis dapat dirumuskan sebagai upaya meminimalkan jumlah kuadrat residual. Jika memiliki data variabel $y$ dan $x$ sebanyak $n$, maka parameter $\beta_{0}$ dan $\beta_{1}$ (yang merupakan intersep dan slope garis tersebut), dapat diperoleh dengan menyelesaikan masalah berikut:

$\operatorname{Min}_{\beta_{0} \beta_{1}} \sum_{i=1}^{n} u_{i}^{2}\left(=\sum_{i=1}^{n}\left(y-\beta_{0}-\beta_{1} x\right)^{2}\right)$

Dengan menggunakan teknik kalkulus dan penerapan aturan penjumlahan dapat ditunjukkan bahwa parameter $\beta_{0}$ dan $\beta_{1}$ adalah:

$\widehat{\beta_{1}}=\frac{\sum_{i=1}^{n}\left(x_{i}-\bar{x}\right)\left(y_{i}-\bar{y}\right)}{\sum_{i=1}^{n}\left(x_{i}-\bar{x}\right)^{2}}=\frac{\operatorname{Cov}(x, y)}{\operatorname{Var}(x)}$

$\widehat{\beta_{0}}=\bar{y}-\beta_{1} \bar{x}$

Parameter yang diperoleh dari persamaan disebut dengan estimator OLS. Dari estimator ini, diperoleh nilai prediksi (fitted value) dari $y$ ketika $x=x_{i}$, yang diberikan sebagai

$\widehat{y_{i}}=\widehat{\beta_{0}}+\widehat{\beta_{1}} x_{i}$

Regresi yang diperoleh di atas adalah estimasi dari PRF. Data sampel yang lain akan memberikan SRF yang berbeda, yang mungkin lebih dekat (atau mungkin juga tidak) dengan PRF.

yakni

Estimasi dengan menggunakan OLS mengasumsikan tiga hal penting,

$\begin{array}{lll}E\left(u_{i}\right) & =0 & \ldots \ldots \ldots(11) \\ \operatorname{var}\left(u_{i}\right) & =\sigma^{2} & \ldots \ldots \ldots(12) \\ \operatorname{cov}\left(u_{i}, u_{j}\right) & =0 & \ldots \ldots \ldots(13) \\ \operatorname{cov}\left(x_{i}, u_{i}\right) & =0 & \ldots \ldots \ldots(14) \\ u_{i} \sim N\left(0, \sigma^{2}\right) & \ldots \ldots \ldots \ldots \ldots . \ldots(15)\end{array}$

Asumsi $E\left(u_{i}\right)=0$, menyatakan bahwa, rata-rata dari residual adalah nol. Asumsi ini tercapai khususnya jika kita mengasumsikan bahwa parameter intersep adalah bukan nol. Asumsi $\left.\operatorname{var}\left(u_{i}\right)=\sigma^{2}\right)$ menyatakan varians dari residual adalah bersifat konstan (disebut sebagai homoskedastisitas).

Asumsi $\operatorname{cov}\left(u_{i}, u_{j}\right)=0$ dan $\operatorname{cov}\left(x_{i}, u_{i}\right)=0$, menyatakan bahwa tidak ada korelasi baik di antara residual maupun antara residual dan variabel independen. Asumsi $\operatorname{cov}\left(x_{i}, u_{i}\right)=0$ sangat sulit dipenuhi mengingat model yang diestimasi di sini hanya memiliki satu variabel independen. Akhirnya asumsi $u_{i} \sim N\left(0, \sigma^{2}\right)$ 
menyatakan bahwa residual terdistribusi secara normal dengan rata-rata nol dan varians konstan. Apabila asumsi-asumsi ini (disebut juga asumsi regresi linear klasik) terpenuhi maka dapat ditunjukkan bahwa estimator OLS adalah bersifat Best Linear Unbiased Estimator (BLUE). Ini adalah estimator tak bias terbaik di kelas estimator linear.

\section{Model Rata-Rata Bergerak (Moving Average) Simple Moving Average}

Metode lain dalam peramalan adalah metode rata-rata bergerak (moving average). Metode ini memberikan informasi mengenai peramalan rata-rata nilai dengan menggunakan sejumlah data aktual terbaru (Stevenson, 2011). Metode ini berusaha memperbaiki kelemahan metode naif (naïve method) yang memberikan informasi peramalan hanya melalui penelusuran data aktual dengan lag satu periode. Oleh karena itu, dengan memperluas jumlah data historis, maka kelemahan tersebut dapat diatasi. Persamaan peramalan dengan metode rata-rata bergerak.

$F_{t+1}=M A_{n}=\frac{\sum_{t=1}^{n} A_{t-1}}{n}=\frac{A_{t-n}+\cdots+A_{t-2}+A_{t-1}}{n}$

Dalam rata-rata bergerak, ketika data aktual terbaru telah tersedia, maka ramalan perlu diperbarui. Pembaruan tersebut dilakukan dengan menambahkan nilai terbaru dan menjatuhkan nilai yang paling lampau, kemudian menghitung ulang nilai rata-rata.

Metode rata-rata bergerak dapat menggunakan sejumlah poin data sesuai yang diinginkan oleh pembuat keputusan. Dalam memilih jumlah periode untuk disertakan dalam penghitungan, pembuat keputusan harus memperhitungkan bahwa jumlah poin data yang berada di sekitar nilai rata-rata akan menentukan kepekaannya terhadap setiap titik data baru. Semakin sedikit titik data di sekitar nilai rata-rata, maka nilai rata-rata tersebut cenderung sensitif atau responsif (Stevenson, 2011). Jika respon terhadap data adalah penting, maka rata-rata bergerak dengan data poin yang lebih sedikit dapat digunakan. Hal ini akan memungkinkan respon yang cepat untuk setiap perubahan dalam data, tetapi juga akan menyebabkan ramalan yang dihasilkan menjadi lebih responsif bahkan terhadap variasi acak. Sebaliknya, rata-rata bergerak yang menggunakan poin data lebih banyak maka menghasilkan ramalan yang lebih "halus" namun kurang responsif terhadap perubahan. Oleh karena itu, dalam memilih periode yang sesuai pembuat keputusan harus mempertimbangkan biaya akibat respon yang lebih lambat terhadap perubahan dalam data dan juga biaya akibat respon terhadap variasi acak. Tinjauan mengenai kesalahan peramalan (forecast error) dapat membantu dalam keputusan ini.

Kelebihan dari peramalan menggunakan metode rata-rata bergerak adalah karena metode ini mudah untuk digunakan dan dimengerti. Walaupun demikian, kelemahan metode ini adalah bahwa semua nilai yang dihitung memiliki bobot yang sama (Stevenson, 2011). Misalnya, dalam rata-rata bergerak yang menggunakan 5 periode, setiap nilai memiliki bobot $1 / 5$. Oleh karena itu, nilai yang paling lampau memiliki bobot yang sama dengan nilai yang paling baru. Jika perubahan terjadi dalam data, rata-rata peramalan sulit untuk merespon perubahan, terutama ketika terdapat banyak poin data di sekitar nilai rata-rata. Pengurangan poin data di sekitar nilai rata-rata meningkatkan bobot bagi data 
yang lebih baru, tetapi hal ini akan mengorbankan informasi potensial dari data yang ada.

\section{Weighted Moving Average}

Rata-rata tertimbang mirip dengan rata-rata bergerak, namun metode ini memberikan bobot lebih pada nilai-nilai yang paling baru dalam data runtut waktu (time series) (Stevenson, 2011). Misalnya, nilai yang paling baru diberi bobot 0,40 ; nilai sebelumnya diberi bobot 0,30 ; lalu 0,20 ; dan yang paling lampau diberi bobot 0,10 . Perhatikan bahwa ketika bobot dijumlahkan harus sama dengan 1,00; dan bahwa bobot terbesar diberikan pada nilai yang terbaru. Persamaan (3) menjelaskan bagaimana melakukan peramalan dengan metode rata-rata bergerak yang tertimbang.

$F_{t+1}=w_{t}\left(A_{t)}+w_{t-1}\left(A_{t-1}\right)+\cdots+w_{t-n}\left(A_{t-n}\right)\right.$

Kelebihan dari rata-rata bergerak yang tertimbang dibandingkan dengan rata-rata bergerak sederhana adalah bahwa rata-rata tertimbang lebih mencerminkan kejadian yang terbaru. Walaupun demikian, pilihan bobot ditentukan secara arbitrer oleh pembuat kebijakan dan umumnya melibatkan penggunaan trial and error untuk menemukan skema pembobotan yang paling sesuai.

\section{METODE}

Data yang digunakan dalam penelitian ini adalah data sekunder berupa data time series tahunan dengan periode tahun 2002 sampai tahun 2016 dan merupakan penelitian kuantitatif serta studi empiris. Peramalan ke depan dilakukan untuk tahun 2017 sampai tahun 2019. Lokasi penelitian dilakukan menyeluruh untuk seluruh Indonesia. Data yang digunakan dalam penelitian ini adalah data bea cukai Indonesia yang diperoleh dari Direktorat Jenderal Bea Cukai (DJBC), Kementrian Keuangan, Indonesia. Data dikumpulkan dari basis data yang sudah ada. Sumber data didapatkan dari situs website DJBC yaitu www.beacukai.go.id. Analisis data yang digunakan dalam penelitian ini adala analisis yang bersifat deskriptif dan kuantitatif dengan menggunakan beberapa alat analisis, yakni double exponential smoothing, ordinary least square (OLS) dan rata-rata bergerak (moving average).

\section{HASIL}

\section{Model Double Exponential Smoothing}

Pemodelan dan Peramalan Bea Masuk

Tabel 1 menjelaskan hasil forecasting data bea masuk secara tahunan dari tahun 2017 hingga 2019 menggunakan metode double exponential smoothing. Selanjutnya, pada model ini digunakan nilai $\alpha$ dan $\beta$ sebesar 0,9 dan 0,3 .

Tabel 1

Peramalan Bea Masuk Menggunakan Model Double Exponential Smoothing

\begin{tabular}{ccr}
\hline Periode & $\begin{array}{c}\text { Bea Masuk } \\
\text { (Juta Rupiah) }\end{array}$ & $\begin{array}{c}\text { Double Exponential Smoothing } \\
\text { (Juta Rupiah) }\end{array}$ \\
\hline 2002 & $10.556 .319,43$ & 9.763 .853 \\
2003 & $10.981 .314,93$ & 10.839 .665 \\
2004 & $12.091 .217,57$ & 11.882 .482
\end{tabular}




\begin{tabular}{lll}
2005 & $15.054 .716,18$ & 15.364 .081 \\
2006 & $12.114 .330,08$ & 12.086 .600 \\
2007 & $16.730 .389,37$ & 16.773 .659 \\
2008 & $22.955 .883,12$ & 23.000 .164 \\
2009 & $18.234 .519,50$ & 17.888 .923 \\
2010 & $20.023 .426,84$ & 19.955 .071 \\
2011 & $25.344 .500,47$ & 25.319 .491 \\
2012 & $28.364 .076,08$ & 28.579 .596 \\
2013 & $31.921 .512,52$ & 31.458 .297 \\
2014 & $33.073 .846,32$ & 33.164 .042 \\
2015 & $31.559 .920,89$ & 36.883 .438 \\
2016 & $26.404 .321,63$ & 35.787 .363 \\
2017 & & 35.547 .858 \\
2018 & & 35.381 .388 \\
2019 & & 35.265 .880 \\
\hline
\end{tabular}

Sumber: Data diolah

Pemodelan dan Peramalan Bea Keluar

Tabel 2

Peramalan Bea Keluar Menggunakan Model Double Exponential Smoothing

\begin{tabular}{crr}
\hline Periode & $\begin{array}{c}\text { Bea Keluar } \\
\text { (Juta Rupiah) }\end{array}$ & $\begin{array}{r}\text { Double Exponential Smoothing } \\
\text { (Juta Rupiah) }\end{array}$ \\
\hline 2002 & 230.168 & 140.574 \\
2003 & 230.259 & 150.677 \\
2004 & 297.790 & 221.687 \\
2005 & 317.892 & 236.979 \\
2006 & 1.091 .083 & 1.259 .343 \\
2007 & 3.577 .246 & 2.421 .815 \\
2008 & 13.597 .000 & 14.743 .003 \\
2009 & 537.638 & 1.856 .365 \\
2010 & 8.788 .289 & 5.979 .971 \\
2011 & 28.827 .090 & 29.998 .252 \\
2012 & 21.473 .170 & 24.655 .105 \\
2013 & 16.102 .520 & 17.528 .184 \\
2014 & 11.695 .089 & 15.367 .196 \\
2015 & 3.815 .536 & 9.997 .239 \\
2016 & 2.271 .121 & 13.841 .298 \\
2017 & & 19.322 .560 \\
2018 & & 27.138 .079 \\
2019 & & 38.281 .693 \\
\hline
\end{tabular}

Sumber: Data diolah

Tabel 2 menjelaskan hasil forecasting data bea keluar secara tahunan dari tahun 2017 hingga 2019 menggunakan metode double exponential. Selanjutnya, pada model ini digunakan nilai $\alpha$ dan $\beta$ sebesar 0,3 dan 0,1 . 
Pemodelan dan Peramalan Cukai

Tabel 3

Peramalan Cukai Menggunakan Model Double Exponential Smoothing

\begin{tabular}{crr}
\hline Periode & $\begin{array}{c}\text { Cukai (Juta } \\
\text { Rupiah) }\end{array}$ & $\begin{array}{c}\text { Double Exponential Smoothing } \\
\text { (Juta Rupiah) }\end{array}$ \\
\hline 2002 & $23.327 .417,26$ & $15.370 .683,40$ \\
2003 & $26.397 .347,02$ & $26.354 .932,43$ \\
2004 & $28.368 .529,87$ & $28.378 .355,79$ \\
2005 & $33.017 .626,27$ & $32.651 .772,85$ \\
2006 & $37.261 .695,73$ & $38.184 .669,60$ \\
2007 & $44.746 .244,32$ & $45.200 .618,89$ \\
2008 & $51.034 .463,97$ & $50.931 .007,45$ \\
2009 & $56.716 .560,58$ & $55.038 .852,34$ \\
2010 & $66.091 .300,20$ & $65.592 .316,97$ \\
2011 & $77.052 .571,01$ & $76.989 .838,94$ \\
2012 & $94.836 .509,51$ & $97.137 .223,15$ \\
2013 & $108.403 .409,15$ & $107.023 .627,38$ \\
2014 & $163.457 .114,51$ & $140.274 .991,02$ \\
2015 & $144.561 .592,25$ & $384.731 .195,93$ \\
2016 & $92.510 .748,97$ & $365.956 .064,52$ \\
2017 & & $364.931 .715,02$ \\
2018 & & $364.867 .100,43$ \\
2019 & & $364.863 .039,05$ \\
\hline
\end{tabular}

Sumber: Data diolah

Tabel 3 menjelaskan hasil forecasting data cukai secara tahunan dari tahun 2015 hingga 2019 menggunakan metode double exponential.Selanjutnya, pada model ini digunakan nilai $\alpha$ dan $\beta$ sebesar 0,9 dan 0,2 .

\section{Model Ordinary Least Square (OLS)}

Dalam pemodelan menggunakan metodel ordinary least square digunakan beberapa variabel makro penting untuk menyusun model peramalan, yaitu (1) suku bunga pinjaman, (2) suku bunga simpanan, (3) harga minyak mentah dunia, (4) tingkat ekspor riil, (5) nilai tukar IDR/USD, (6) indeks harga saham gabungan (IHSG), (7) tingkat inflasi, (8) tingkat impor riil, (9) realisasi investasi domestik, (10) realisasi investasi asing, dan (11) pendapatan domestik bruto riil.

\section{Pemodelan dan Peramalan Bea Masuk}

Hasil pemodelan menggunakan metode ordinary least square untuk data bea masuk dijelaskan dalam Tabel 4 Koefisien yang dihasilkan dari regresi lalu digunakan untuk meramalkan tingkat bea masuk lima tahun ke depan. Nilai $\mathrm{R}^{2}$ dari model yang dihasilkan cukup tinggi yaitu 0,911050, hal ini menunjukkan bahwa variasi dalam variabel independen dapat menjelaskan variasi variabel dependen (bea masuk). 


\section{Tabel 4}

Model Ordinary Least Square untuk Bea Masuk

\begin{tabular}{crrrl}
\hline Variable & Coefficient & Std. Error & t-Statistic & Prob. \\
\hline BUNGAPINJAMAN & -71205.52 & 72499.96 & -0.982146 & 0.3328 \\
BUNGASIMPANAN & 147748.0 & 68437.83 & 2.158865 & 0.0378 \\
CRUDEOILPRICE & 3033.715 & 3121.652 & 0.971830 & 0.3378 \\
EKSPORTRIIL & 5.206680 & 5.306120 & 0.981259 & 0.3332 \\
FOREX & 95.76407 & 55.81347 & 1.715788 & 0.0950 \\
IHSG & -146.0229 & 141.2805 & -1.033567 & 0.3084 \\
\hline Variable & Coefficient & Std. Error & t-Statistic & Prob. \\
\hline IMPORTRIIL & 0.943011 & 5.450562 & 0.173012 & 0.8636 \\
INVREALDOM & 9.965062 & 8.258849 & 1.206592 & 0.2357 \\
INVREALFOREIGN & 19.65205 & 31.94052 & 0.615270 & 0.5424 \\
PDBRIIL & 2.628043 & 2.098601 & 1.252284 & 0.2188 \\
C & -1526871. & 1520316. & -1.004311 & 0.3221 \\
\hline R-squared & 0.911050 & Mean dependent var & 1760415. \\
Adjusted R-squared & 0.883094 & S.D. dependent var & 644623.1 \\
S.E. of regression & 220406.1 & Akaike info criterion & 27.66017 \\
Sum squared resid & $1.70 E+12$ & Schwarz criterion & 28.13255 \\
Log likelihood & -638.0140 & Hannan-Quinn criter. & 27.83793 \\
F-statistic & 32.58906 & Durbin-Watson stat & 1.632501 \\
Prob(F-statistic) & 0.000000 & & & \\
\hline Suber Data & & &
\end{tabular}

Sumber: Data diolah

Tabel 5 menunjukkan hasil peramalan menggunakan metode ordinary least square hingga tahun 2019. Hasil estimasi yang tersedia dalam tabel adalah rata-rata penerimaan selama tiga bulan sehingga untuk estimasi penerimaan bea masuk per tahun adalah jumlah total per tahun dikalikan tiga. Hal tersebut karena data variabel independen yang digunakan adalah data bulanan yang tidak dapat diakumulasikan, seperti suku bunga pinjaman, suku bunga simpanan, harga minyak mentah, nilai tukar, dan inflasi.

Tabel 5

Peramalan Bea Masuk Menggunakan Model OLS

\begin{tabular}{ccc}
\hline Periode & Bulan & Peramalan Bea Masuk (Juta Rupiah) \\
\hline \multirow{4}{*}{2017} & 3 & $2.958 .785,91$ \\
& 6 & $2.958 .801,71$ \\
& 9 & $2.958 .798,10$ \\
& 12 & $2.958 .796,74$ \\
2018 & 3 & $2.958 .798,14$ \\
& 6 & $2.958 .797,71$ \\
& 9 & $2.958 .797,65$ \\
2019 & 12 & $2.958 .797,77$ \\
& 3 & $2.958 .797,72$ \\
& 6 & $2.958 .797,72$ \\
& 12 & $2.958 .797,73$ \\
\end{tabular}

Sumber: Data diolah 


\section{Pemodelan dan Peramalan Bea Keluar}

Hasil pemodelan menggunakan metode ordinary least square untuk data bea keluar dijelaskan dalam Tabel 6 Koefisien yang dihasilkan dari regresi lalu digunakan untuk meramalkan tingkat bea masuk lima tahun ke depan. Nilai $\mathrm{R}^{2}$ dari model yang dihasilkan cukup tinggi yaitu 0,818614 , hal ini menunjukkan bahwa variasi dalam variabel independen dapat menjelaskan variasi variabel dependen (bea keluar).

\section{Tabel 6}

Model Ordinary Least Square untuk Bea Keluar

\begin{tabular}{crrrr}
\hline \hline Variable & Coefficient & Std. Error & t-Statistic & Prob. \\
\hline BUNGAPINJAMAN & -167997.0 & 145382.4 & -1.155553 & 0.2557 \\
BUNGASIMPANAN & 340553.4 & 137236.7 & 2.481505 & 0.0180 \\
CRUDEOILPRICE & 25950.38 & 6259.770 & 4.145581 & 0.0002 \\
EKSPORTRIIL & 14.68226 & 10.64023 & 1.379882 & 0.1764 \\
FOREX & -243.5772 & 111.9214 & -2.176325 & 0.0364 \\
IHSG & -348.7828 & 283.3063 & -1.231116 & 0.2265 \\
INFLASI & -9264.334 & 3820.333 & -2.425007 & 0.0206 \\
IMPORTRIIL & -9.112778 & 10.92988 & -0.833750 & 0.4101 \\
INVREALDOM & 9.481592 & 16.56126 & 0.572516 & 0.5706 \\
INVREALFOREIGN & 75.67941 & 64.04952 & 1.181577 & 0.2453 \\
PDBRIIL & 0.820547 & 4.208271 & 0.194984 & 0.8465 \\
C & 710465.7 & 3048652. & 0.233043 & 0.8171 \\
\hline R-squared & 0.818614 & Mean dependent var & 764917.4 \\
Adjusted R-squared & 0.761607 & S.D. dependent var & 905213.4 \\
S.E. of regression & 441974.9 & Akaike info criterion & 29.05173 \\
Sum squared resid & $6.84 E+12$ & Schwarz criterion & 29.52411 \\
Log likelihood & -670.7157 & Hannan-Quinn criter. & 29.22949 \\
F-statistic & 14.35989 & Durbin-Watson stat & 2.064202 \\
Prob(F-statistic) & 0.000000 & & \\
\hline
\end{tabular}

Sumber: Data diolah

Tabel 7 menunjukkan hasil peramalan menggunakan metode ordinary least square hingga tahun 2019. Hasil estimasi yang tersedia dalam tabel adalah rata-rata penerimaan selama tiga bulan sehingga untuk estimasi penerimaan bea keluar per tahun adalah jumlah total per tahun dikalikan tiga. Hal tersebut karena data variabel independen yang digunakan adalah data bulanan yang tidak dapat diakumulasikan, seperti suku bunga pinjaman, suku bunga simpanan, harga minyak mentah, nilai tukar, dan inflasi.

Tabel 7

Peramalan Bea Keluar Menggunakan Model Ordinary Least Square

\begin{tabular}{ccc}
\hline Periode & Bulan & Peramalan Bea Keluar (Juta Rupiah) \\
\hline \multirow{2}{*}{2017} & 3 & 1.201 .265 \\
& 6 & 1.201 .208 \\
2018 & 9 & 1.201 .207 \\
& 12 & 1.201 .219 \\
& 3 & 1.201 .213
\end{tabular}




$\begin{array}{ccc} & 6 & 1.201 .213 \\ & 9 & 1.201 .214 \\ & 12 & 1.201 .214 \\ 2019 & 3 & 1.201 .214 \\ & 6 & 1.201 .214 \\ & 9 & 1.201 .214 \\ & 12 & 1.201 .214\end{array}$

Sumber: Data diolah

\section{Pemodelan dan Peramalan Cukai}

Hasil pemodelan menggunakan metode ordinary least square untuk data cukai dijelaskan dalam Tabel 8 Koefisien yang dihasilkan dari regresi lalu digunakan untuk meramalkan tingkat cukai lima tahun ke depan. Nilai $\mathrm{R}^{2}$ dari model yang dihasilkan cukup tinggi yaitu 0,893329, hal ini menunjukkan bahwa variasi dalam variabel independen dapat menjelaskan variasi variabel dependen (cukai).

Tabel 8

Model Ordinary Least Square untuk Cukai

\begin{tabular}{crcrc}
\hline Variable & Coefficient & Std. Error & t-Statistic & Prob. \\
\hline BUNGAPINJAMAN & -134482.4 & 289383.9 & -0.464720 & 0.6450 \\
BUNGASIMPANAN & 307868.8 & 273169.9 & 1.127023 & 0.2674 \\
CRUDEOILPRICE & -19067.47 & 12460.09 & -1.530284 & 0.1349 \\
EKSPORTRIIL & -6.285449 & 21.17940 & -0.296772 & 0.7684 \\
FOREX & -360.3519 & 222.7797 & -1.617526 & 0.1147 \\
IHSG & -1622.511 & 563.9218 & -2.877192 & 0.0068 \\
Variable & Coefficient & Std. Error & t-Statistic & Prob. \\
INFLASI & -3532.651 & 7604.383 & -0.464555 & 0.6451 \\
IMPORTRIIL & 34.47776 & 21.75594 & 1.584752 & 0.1220 \\
INVREALDOM & 77.83678 & 32.96523 & 2.361178 & 0.0239 \\
INVREALFOREIGN & 113.6154 & 127.4907 & 0.891166 & 0.3789 \\
PDBRIIL & 29.66993 & 8.376573 & 3.542012 & 0.0011 \\
C & -7729784. & 6068348. & -1.273787 & 0.2111 \\
\hline R-squared & 0.893329 & Mean dependent var & 4841856. \\
Adjusted R-squared & 0.859803 & S.D. dependent var & 2349587. \\
S.E. of regression & 879752.0 & Akaike info criterion & 30.42851 \\
Sum squared resid & $2.71 E+13$ & Schwarz criterion & 30.90088 \\
Log likelihood & -703.0699 & Hannan-Quinn criter. & 30.60627 \\
F-statistic & 26.64642 & Durbin-Watson stat & 2.559162 \\
Prob(F-statistic) & 0.000000 & & \\
\hline Sumber Data diol & & &
\end{tabular}

Sumber: Data diolah

Tabel 9 menunjukkan hasil peramalan menggunakan metode ordinary least square hingga tahun 2019. Hasil estimasi yang tersedia dalam tabel adalah rata-rata penerimaan selama tiga bulan sehingga untuk estimasi penerimaan cukai per tahun adalah jumlah total per tahun dikalikan tiga. Hal tersebut karena data variabel independen yang digunakan adalah data bulanan yang tidak dapat 
diakumulasikan, seperti suku bunga pinjaman, suku bunga simpanan, harga minyak mentah, nilai tukar, dan inflasi.

Tabel 9

Peramalan Cukai Menggunakan Model OLS

\begin{tabular}{lrr}
\hline Periode & \multicolumn{1}{c}{ Bulan } & Peramalan Cukai (Juta Rupiah) \\
\hline \multirow{3}{*}{2017} & 3 & 8.745 .213 \\
& 6 & 8.745 .323 \\
9 & 8.745 .309 \\
& 12 & 8.745 .294 \\
2018 & 3 & 8.745 .304 \\
& 6 & 8.745 .302 \\
& 9 & 8.745 .301 \\
& 12 & 8.745 .302 \\
2019 & 3 & 8.745 .302 \\
& 6 & 8.745 .302 \\
& 9 & 8.745 .302 \\
& 12 & 8.745 .302
\end{tabular}

Sumber: Data diolah

Model Rata-rata Bergerak (Moving Average)

Pemodelan dan Peramalan Bea Masuk

Tabel 10

Peramalan Bea Masuk Menggunakan Model Moving Average dan Weighted Moving Average

\begin{tabular}{ccrr}
\hline Periode & $\begin{array}{c}\text { Bea Masuk } \\
\text { (Juta Rupiah) }\end{array}$ & $\begin{array}{c}\text { Moving Average } \\
\text { (Juta Rupiah) }\end{array}$ & $\begin{array}{c}\text { Weighted Moving Average } \\
\text { (Juta Rupiah) }\end{array}$ \\
\hline 2002 & $10.556 .319,43$ & 7.904 .851 & 7.978 .824 \\
2003 & $10.981 .314,93$ & 11.059 .039 & 11.004 .605 \\
2004 & $12.091 .217,57$ & 11.463 .777 & 11.543 .491 \\
2005 & $15.054 .716,18$ & 15.102 .642 & 15.131 .466 \\
2006 & $12.114 .330,08$ & 12.251 .137 & 12.234 .835 \\
2007 & $16.730 .389,37$ & 15.991 .153 & 16.114 .830 \\
2008 & $22.955 .883,12$ & 21.866 .408 & 22.052 .049 \\
2009 & $18.234 .519,50$ & 18.859 .633 & 18.715 .385 \\
2010 & $20.023 .426,84$ & 19.814 .930 & 19.821 .223 \\
2011 & $25.344 .500,47$ & 24.293 .218 & 24.472 .810 \\
2012 & $28.364 .076,08$ & 28.135 .459 & 28.205 .567 \\
2013 & $31.921 .512,52$ & 30.651 .619 & 30.792 .433 \\
2014 & $33.073 .846,32$ & 33.283 .533 & 33.236 .957 \\
2015 & $31.559 .920,89$ & 36.282 .248 & 36.778 .154 \\
2016 & $26.404 .321,63$ & 36.372 .226 & 36.823 .833 \\
2017 & & 36.372 .462 & 36.823 .837 \\
2018 & & 36.372 .467 & 36.823 .837 \\
2019 & & 36.372 .467 & 36.823 .837 \\
\hline
\end{tabular}

Sumber: Data diolah 
Tabel 10 menjelaskan hasil forecasting data bea masuk secara tahunan dari tahun 2017 hingga 2019 menggunakan metode moving average dan weighted moving average. Jumlah periode yang digunakan dalam metode moving average dan weighted moving average adalah tiga periode. Selanjutnya, pada model weighted moving average juga digunakan pembobotan sebesar 0,5 untuk periode yang paling dekat dengan periode forecasting, lalu 0,3; dan periode yang paling jauh dengan periode forecasting diberi bobot 0,2 .

\section{Pemodelan dan Peramalan Bea Keluar}

Tabel 11

Peramalan Bea Keluar Menggunakan Model Moving Average dan Weighted Moving Average

\begin{tabular}{crrr}
\hline Periode & $\begin{array}{c}\text { Bea Keluar } \\
\text { (Juta Rupiah) }\end{array}$ & \multicolumn{1}{c}{$\begin{array}{c}\text { MA (Juta } \\
\text { Rupiah) }\end{array}$} & \multicolumn{1}{c}{$\begin{array}{c}\text { WMA (Juta } \\
\text { Rupiah) }\end{array}$} \\
\hline 2002 & 230.168 & 172.561 & 173.680 \\
2003 & 230.259 & 222.402 & 222.958 \\
2004 & 297.790 & 297.377 & 297.137 \\
2005 & 317.892 & 301.504 & 303.701 \\
2006 & 1.091 .083 & 1.408 .064 & 1.381 .674 \\
2007 & 3.577 .246 & 2.078 .316 & 2.318 .342 \\
2008 & 13.597 .000 & 14.620 .679 & 14.482 .856 \\
2009 & 537.638 & 746.686 & 663.981 \\
2010 & 8.788 .289 & 4.811 .719 & 5.236 .978 \\
2011 & 28.827 .090 & 28.932 .739 & 29.086 .468 \\
2012 & 21.473 .170 & 22.418 .222 & 22.327 .332 \\
2013 & 16.102 .520 & 15.197 .271 & 15.167 .971 \\
2014 & 11.695 .089 & 14.754 .745 & 14.508 .869 \\
2015 & 3.815 .536 & 4.804 .656 & 4.084 .851 \\
2016 & 2.271 .121 & 4.708 .893 & 4.024 .050 \\
2017 & & 4.708 .692 & 4.024 .042 \\
2018 & & 4.708 .691 & 4.024 .042 \\
2019 & & 4.708 .691 & 4.024 .042 \\
\hline
\end{tabular}

Sumber: Data diolah

Tabel 11 menjelaskan hasil forecasting data bea keluar secara tahunan dari tahun 2017 hingga 2019 menggunakan metode moving average dan weighted moving average. Jumlah periode yang digunakan dalam metode moving average dan weighted moving average adalah tiga periode. Selanjutnya, pada model weighted moving average juga digunakan pembobotan sebesar 0,5 untuk periode yang paling dekat dengan periode forecasting, lalu 0,3 ; dan periode yang paling jauh dengan periode forecasting diberi bobot 0,2. 
Pemodelan dan Peramalan Cukai

Tabel 12

Peramalan Cukai Menggunakan Model Moving Average dan Weighted Moving Average

\begin{tabular}{cccc}
\hline Periode & $\begin{array}{c}\text { Cukai (Juta } \\
\text { Rupiah) }\end{array}$ & $\begin{array}{c}\text { MA (Juta } \\
\text { Rupiah) }\end{array}$ & $\begin{array}{c}\text { WMA (Juta } \\
\text { Rupiah) }\end{array}$ \\
\hline 2002 & $23.327 .417,26$ & $16.313 .471,08$ & $16.668 .036,34$ \\
2003 & $26.397 .347,02$ & $26.388 .480,78$ & $26.425 .556,63$ \\
2004 & $28.368 .529,87$ & $28.742 .793,16$ & $28.633 .461,49$ \\
2005 & $33.017 .626,27$ & $31.932 .635,05$ & $32.042 .039,40$ \\
2006 & $37.261 .695,73$ & $36.722 .390,28$ & $36.994 .544,71$ \\
2007 & $44.746 .244,32$ & $44.124 .502,88$ & $44.277 .041,39$ \\
2008 & $51.034 .463,97$ & $50.176 .735,03$ & $50.233 .059,39$ \\
2009 & $56.716 .560,58$ & $54.332 .128,03$ & $54.477 .597,83$ \\
2010 & $66.091 .300,20$ & $64.806 .497,11$ & $64.854 .952,41$ \\
2011 & $77.052 .571,01$ & $74.399 .284,66$ & $74.805 .592,02$ \\
2012 & $94.836 .509,51$ & $92.986 .694,19$ & $93.671 .173,02$ \\
2013 & $108.403 .409,15$ & $105.293 .046,66$ & $105.514 .012,38$ \\
2014 & $163.457 .114,51$ & $122.089 .013,78$ & $126.142 .743,96$ \\
2015 & $144.561 .592,25$ & $361.881 .504,20$ & $364.160 .585,97$ \\
2016 & $92.510 .748,97$ & $364.861 .837,96$ & $364.861 .999,26$ \\
2017 & & $364.862 .771,15$ & $364.862 .767,06$ \\
2018 & & $364.862 .766,69$ & $364.862 .766,69$ \\
2019 & & $364.862 .766,69$ & $364.862 .766,69$
\end{tabular}

Sumber: Data diolah

Tabel 12 menjelaskan hasil peramalan data cukai secara tahunan dari tahun 2017 hingga 2019 menggunakan metode moving average dan weighted moving average. Jumlah periode yang digunakan dalam metode moving average dan weighted moving average adalah tiga periode. Selanjutnya, pada model weighted moving average juga digunakan pembobotan sebesar 0,5 untuk periode yang paling dekat dengan periode peramalan, lalu 0,3 ; dan periode yang paling jauh dengan periode peramalan diberi bobot 0,2 .

Pemilihan Model Peramalan Terbaik

Bea Masuk

Tabel 13

Hasil Penghitungan Sum Squared Error (SSE) Model Peramalan Bea Masuk

\begin{tabular}{lr}
\hline \multicolumn{1}{c}{ Model Peramalan } & \multicolumn{1}{c}{ SSE } \\
\hline Double Exponential & $1.19 \mathrm{E}+12^{*}$ \\
OLS & $1.79 \mathrm{E}+12$ \\
Moving Average & $1.24 \mathrm{E}+13$ \\
Weighted Moving Average & $1.05 \mathrm{E}+13$ \\
\hline
\end{tabular}

Sumber: Data diolah

Ket: * bertanda merah adalah nilai terkecil 
Tabel 13 menunjukkkan model double exponential smoothing adalah model terbaik dalam memprediksi penerimaan bea masuk dilihat dari nilai SSE. Nilai SSE sebesar 1.19E+12 adalah nilai terkecil dari model lainnya. Jadi, dari kelima model yang diuji tersebut, dapat disimpulkan bahwa model double exponential adalah model terbaik untuk meramalkan penerimaan bea masuk.

\section{Bea Keluar}

\section{Tabel 14}

Hasil Penghitungan Sum Squared Error (SSE) Model Peramalan Bea Keluar

\begin{tabular}{lc}
\hline \multicolumn{1}{c}{ Model Peramalan } & SSE \\
\hline Double Exponential & $3.93 \mathrm{E}+13$ \\
OLS & $6.9 \mathrm{E}+12^{*}$ \\
Moving Average & $3.03 \mathrm{E}+13$ \\
Weighted Moving Average & $2.47 \mathrm{E}+13$ \\
\hline
\end{tabular}

Sumber: Data diolah

Ket: * bertanda merah adalah nilai terkecil

Tabel 14 menunjukkkan model OLS adalah model terbaik dalam memprediksi penerimaan bea keluar dilihat dari nilai SSE. Nilai SSE sebesar 6.9E+12 adalah nilai terkecil dari model lainnya. Jadi, dari kelima model yang diuji tersebut, dapat disimpulkan bahwa model OLS adalah model terbaik untuk meramalkan penerimaan bea keluar.

\section{Cukai}

Tabel 15

Hasil Penghitungan Sum Squared Error (SSE) Model Peramalan Cukai

Sumber: Data diolah

\begin{tabular}{lr}
\hline \multicolumn{1}{c}{ Model Peramalan } & \multicolumn{1}{c}{ SSE } \\
\hline Double Exponential & $6.12 \mathrm{E}+14$ \\
OLS & $2.71 \mathrm{E}+13^{*}$ \\
Moving Average & $1.79 \mathrm{E}+15$ \\
Weighted Moving Average & $1.79 \mathrm{E}+15$ \\
\hline
\end{tabular}

Ket: * bertanda merah adalah nilai terkecil

Tabel 15 menunjukkkan model OLS adalah model terbaik dalam memprediksi penerimaan cukai dilihat dari nilai SSE. Nilai SSE sebesar 2.71E+13 adalah nilai terkecil dari model lainnya. Jadi, dari kelima model yang diuji tersebut, dapat disimpulkan bahwa model OLS adalah model terbaik untuk meramalkan penerimaan cukai.

\section{SIMPULAN}

Berdasarkan hasil yang diperoleh, ada beberapa kesimpulan yang dapat diambil dalam penelitian ini.

1. Berdasarkan plotting data penerimaa bea dan cukai, masing-masing jenis penerimaan memiliki pola yang relatif fluktuatif sehingga secara natural lebih 
sulit untuk diprediksi dibandingkan jenis penerimaan yang memiliki basis penerimaan lebih pasti seperti pajak. Fluktuasi penerimaan ini dipengaruhi terutama oleh variabl-variabel eksogen yagn tidak dapat atau sulit dikendalikan oleh pemerintah, seperti harga minyak dan permintaan ekspor.

2. Pola pergerakan data menentukan jenis metode yang tepat digunakan untuk melakukan estimasi. Dengan menggunakan berbagai model forecasting dan kriteria Sum Squared Error (SSE) diperoleh bahwa metode estimasi bea masuk terbaik adalah double exponential smoothing sedangkan metode estimasi terbaik untuk bea keluar dan cukai adalah dengan menggunakan metode ordinary least square (OLS). Untuk tujuan peramalan, kemampuan model regresi untuk memprediksi nilai di masa depan ditunjukkan oleh tingginya nilai koefisien determinasi $\left(R^{2}\right)$. Model regresi bea keluar memiliki koefisien determinasi sebesar 0,8 sedangkan model regresi cukai memiliki koefisien determinasi sebesar 0,9 .

3. Dengan menggunakan metode double exponential smoothing, penerimaan bea masuk diprediksikan relatif tidak banyak berubah dari tahun 2017-2019 bahkan cenderung mengalami penurunan. Prediksi penerimaan bea masuk pada tahun 2017 hingga 2019 diprediksi sebesar 35,55 triliun, 35, 38 triliun, dan 35,27 triliun rupiah.

4. Dengan menggunakan metode OLS, proyeksi penerimaan bea keluar pada periode 2017-2019 relatif tidak banyak berubah dengan nilai estimasi sebesar 14,4 triliun rupiah tiap tahunnya.

5. Dengan menggunakan metode OLS, proyeksi penerimaan cukai pada periode 2017-2019 diestimasi sebesar 105 triliun rupiah dengan variasi nilai estimasi per tahun yang sangat kecil.

\section{DAFTAR PUSTAKA}

Andini, T.D \& Auristandi, P. (2016). Peramalan Jumlah Stok Alat Tulis Kantor di UD ACHMAD JAYA Menggunakan Metode Double Exponential Smoothing. Jurnal Ilmiah Teknologi dan Informasi ASIA (JITIKA), Vol.10, No.1, Februari 2016. STMIK ASIA, Malang.

Ariefianto, D., M. (2012). Ekonometrika; Esensi dan Aplikasi dengan Menggunakan Eviews. Erlangga. Jakarta.

Aritonang, R. (2009). Peramalan Bisnis. Ghalia Indonesia. Jakarta.

Box, G. P., \& Jenkins, G. M. (1976). Time Series Analysis: Forecasting and Control. San Fransisco: Holden-Day.

Cooray, T. (2008). Applied Time Series. Oxford: Alpha Science Intl Ltd.

Departemen Keuangan. (2014). Nota Keuangan dan RAPBN 2015, www.anggaran.depkeu.co.id/dja/acontent/NKRAPBN2015.pdf, diakses 22 Desember 2014

Firdaus. M. (2006). Analisis Deret Waktu Satu Ragam. Bogor: IPB Press.

Hartanti, O.D. (2014). Perbandingan Hasil Peramalan dengan Metode Double Exponential Smoothing Holt dan Metode Jaringan Syaraf Tiruan. Jurnal Biometrika dan Kependudukan, Vol.3, No.2, Desember 2014. Universitas Airlangga, Surabaya.

Hanke, J. E \& Reitsch, A. G. (1998). Business Forecasting. Sixth Edition, Upper Saddle River, New Jersey: Prentice Hall. 
Hidayat, A. (2014). Kewenangan Otoritas Pajak untuk Meningkatkan Tax Ratio, www.pajak.go.id/content/artikel/kewenangan-otoritas-pajak-untukmeningkatkan-tax-ratio/, diakses 21 Desember 2014

Kuncoro, M. (2001). Manajemen Keuangan Internasional: Pengantar Ekonomi dan Bisnis Global, Edisi Kedua. BPFE. Yogyakarta.

Kurniawan, Y.A \& Nurhadiyono, B. (2015). Komparasi Metode Least Square dan Double Exponential Smoothing untuk Menganalisis Pendapatan Retribusi Uji Kendaraan Bermotor. Universitas Dian Nuswantoro, Semarang.

Lutkepohl, H. (1991). Introduction to Multiple Time Series Analysis. Berlin: Spinger-Verlag.

Madura, J. (2004). Manajemen Keuangan Internasional. Jilid 1, Edisi ke 4. Erlangga. Jakarta.

Mentzer, J., \& Moon, M. (2004). Sales Forecasting Management. Los Angeles: SAGE Publications.

Nachrowi, N.D., \& Utsman. H. (2006). Ekonometrika untuk Analisis Ekonomi dan Keuangan Pendekatan Populer dan Praktis, Jakarta: LPFE UI.

Ofori, T \& Ephraim, L. (2012). Vagaries of The Ghanaian Inflation Rates: Application of Exponential Smoothing Technique. International Journal of Research in Environmental Science and Technology 2012; 2 (4): 150-160. University of Mines and Technology, Tarkwa, Ghana.

Pindyck, S. R., \& Rubenfeld, D. L. (1991). Econometric Models and Economics Forecast. New York City: McGraw-Hill.

Stevenson, W. (2011). Operations Management. New York City: McGraw-Hill. 